\title{
A Látrányi Puszta Természetvédelmi Terület szárazföldi ászkarák (Isopoda: Oniscidea) faunája
}

\author{
FARKAS SÁNDOR' és VADKERTI EdIT²
}

\footnotetext{
' Kaposvári Egyetem, Állattudományi Kar, Ökológiai Munkacsoport, H-7401 Kaposvár, Pf. 16., Hungary

2 Pécsi Tudományegyetem, Állatföldrajzi és Ökológiai Tanszék, 7625 Pécs, Ifjúság u. 6., Hungary
}

FARKAS, S., VADKerTI, E.: The terrestrial isopod (Isopoda: Oniscidea) fauna of the Látrányi Puszta Nature Conservation Area

Abstract: The Isopod fauna of Látrányi Puszta Nature Conservation Area was examined by pitfall trapping and hand sampling in 2002. Several habitat types were sampled: sandy grassland, fragment of wetland forest, marsh, alder and oak woods. Nine species were found. Armadillidium zenckeri, Ligidium hypnorum and Trachelipus rathkii occured in the greatest amount. The Isopod assemblage of the wetland forest had the highest Rényi-diversity value.

Key words: Isopod, Armadillidium zenckeri, Ligidium hypnorum, Trachelipus rathkii, habitat preferences, Rényi-diversity

\section{Bevezetés}

A Látrányi Puszta Természetvédelmi Terület szárazföldi ászkarák faunája korábban teljesen ismeretlen volt. A terület élővilágának megismerése céljából, a Somogy Megyei Múzeum Természettudományi Osztálya által indított általános florisztikai és faunisztikai kutatás keretében került sor 2002-ben az ászkarák fauna feltárására. Az alábbiakban e vizsgálatok eredményei kerülnek ismertetésre.

\section{Anyag és módszer}

A terület több, eltérő élöhely mozaikjából tevődik össze, melyek növényzete egymástól markánsan különbözik. Egyes ászkarák fajok határozott preferenciát mutatnak bizonyos élöhelyekkel szemben, míg másokból hiányoznak, ezért igyekeztünk kiválasztani az összes olyan élöhelyet, ahol Isopodák előfordulására számítani lehetett. A mintavételezést talajcsapdázással és egyelő gyüjtéssel végeztük. A talajcsapdákat nyolc élöhelyen helyeztük el, melyek mindegyikébe 5 csapdát ástunk le. Az csapdákat "dobókocka-ötös" mintázatban helyeztük el, ahol a sarok-helyzetủ csapdák távolsága a középsötől $1 \mathrm{~m}$ volt. A csapdákat 3 dl-es mủanyag poharakból alakítottuk ki, melyeket félig töltöttünk 5\%-os ecetsav oldattal. A csapdákat 2002 júniusában telepitettük és két hét müködés után leürítettük, majd eltávolítottuk őket. Az ászkarákokon kívül a csapdákba esett egyéb állatokat a programban résztvevő szakemberek dolgozták fel. A mintavételi helyek földrajzi koordinátáit Magellan Map 330 típusú GPS müszerrel határoztuk meg (1. táblázat). 2002 áprilisában és augusztusában is felkerestük a területet, ahol több élöhelyen kézi gyüjtést végeztünk. A gyüjtéshez $1 \mathrm{~cm}$ lyukméretű avarrostát használtunk, továbbá korhadó fák 
kérgét távolítottuk el kapabaltával. Áprilisban két, névtelen efemer vízfolyás mentén kialakult, nedves élőhelyet választottunk ki: (A) egy kisebb vízfolyást övező keményfa li-

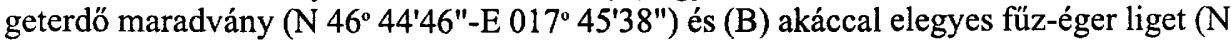
$\left.46^{\circ} 44^{\prime} 35^{\prime \prime}-\mathrm{E} 017^{\circ} 45^{\prime} 51^{\prime \prime}\right)$. Az augusztusi mintavétel során azon élöhelyeket kerestük fel újra, ahol a talajcsapdák egyáltalán nem gyüjtöttek ászkarákokat.

Egyes élőhelyeken tájékozódó jellegü páratartalom és hőmérséklet méréseket is végeztünk.

A gyüjtött anyag határozásához GRUNER (1966) és ScHMÖLZER (1965) határozóit használtuk.

$\mathrm{Az}$ adatok értékelését a NuCoSa programcsomaggal (TóTHMÉRÉSz 1996) végeztük.

A gyüjtött egyedeket jelenleg a Kaposvári Egyetem Isopoda gyüjteményében tároljuk.

1. táblázat: A mintavételi helyek élőhely típusai, koordinátái, tengerszint feletti magassága és az alkalmazott gyüjtési módszer

\begin{tabular}{|c|c|c|c|c|}
\hline \begin{tabular}{|c|} 
Sorszám/ \\
betûjel
\end{tabular} & Élóhely & Koordináta & \begin{tabular}{|c|} 
Magasság \\
$(\mathrm{m})$
\end{tabular} & $\begin{array}{l}\text { Gyûjtési } \\
\text { módszer }\end{array}$ \\
\hline 1. & éger ültetvény & \begin{tabular}{|l|}
$\mathrm{N} 46^{\circ} 44^{\prime} 07^{\prime \prime}-$ \\
$\mathrm{E} 017^{\circ} 46^{\prime} 20^{\prime \prime}$
\end{tabular} & 131 & talajcsapda \\
\hline 2. & $\begin{array}{l}\text { keményfa-liget } \\
\text { fragmentum }\end{array}$ & \begin{tabular}{|l|} 
N $46^{\circ} 44^{\prime} 00^{\prime \prime}-$ \\
E $017^{\circ} 45^{\prime} 50^{\prime \prime}$ \\
\end{tabular} & 128 & talajcsapda \\
\hline 3. & $\begin{array}{l}\text { homoki } \\
\text { sztyepprét I. }\end{array}$ & \begin{tabular}{|l|}
$N 46^{\circ} 44^{\prime} 06^{\prime \prime}-$ \\
E $017^{\circ} 46^{\prime} 07^{\prime \prime}$
\end{tabular} & 126 & talajcsapda \\
\hline 4. & $\begin{array}{l}\text { homoki } \\
\text { sztyepprét II. }\end{array}$ & \begin{tabular}{|l|} 
N $46^{\circ} 43^{\prime} 56^{\prime \prime}-$ \\
E $017^{\circ} 45^{\prime} 57^{\prime \prime}$
\end{tabular} & 137 & talajcsapda \\
\hline 5. & magassásos & \begin{tabular}{|l|}
$N 46^{\circ} 43^{\prime} 58^{\prime \prime}-$ \\
E $017^{\circ} 46^{\prime} 12^{\prime \prime}$ \\
\end{tabular} & 125 & talajcsapda \\
\hline 6. & üde láprét & \begin{tabular}{|l|} 
N $46^{\circ} 43 ' 59^{\prime \prime}-$ \\
E 017 $46^{\prime} 11^{\prime \prime}$ \\
\end{tabular} & 126 & talajcsapda \\
\hline 7. & zsombéksásos & \begin{tabular}{|l|}
$\mathrm{N} 46^{\circ} 44^{\prime} 03^{\prime \prime}-$ \\
$\mathrm{E} 017^{\circ} 45^{\prime} 45^{\prime \prime}$ \\
\end{tabular} & 138 & talajcsapda \\
\hline 8. & tölgy ültet vény & \begin{tabular}{|l|}
$N$ 46 $44^{\circ} 03^{\prime \prime}-$ \\
E $017^{\circ} 45^{\prime} 44^{\prime \prime}$ \\
\end{tabular} & 130 & talajcsapda \\
\hline $\bar{A}$ & $\begin{array}{l}\text { keményfa-liget } \\
\text { fragmentum }\end{array}$ & \begin{tabular}{|l|} 
N $46^{\circ} 44^{\prime} 46^{\prime \prime}-$ \\
E $017^{\circ} 45^{\prime} 38^{\prime \prime}$ \\
\end{tabular} & 119 & $\begin{array}{l}\text { egyelõ } \\
\text { gyûjtés }\end{array}$ \\
\hline B & éger-akác liget & \begin{tabular}{|l|} 
N $46^{\circ} 44^{\prime} 35^{\prime \prime}-$ \\
E $017^{\circ} 45^{\prime} 51^{\prime \prime}$
\end{tabular} & 101 & $\begin{array}{l}\text { egyelõ } \\
\text { gyûjtés }\end{array}$ \\
\hline
\end{tabular}

\section{Eredmények}

A vizsgálat során összesen 262 szárazföldi ászkarákot gyüjtöttünk, melyek 9 fajhoz tartoztak (2. táblázat). Kézi gyüjtéssel 72, talajcsapdázással 190 egyedet fogtunk. A kézi gyüjtések során a fauna kímélése céljából nem szedtünk össze minden egyedet, ezért kvantitatív elemzést csak a talajcsapdák által fogott anyaggal végeztünk.

A két, egymástól távol kijelölt homoki gyepben, valamint a fiatal tölgyesben lerakott csapdák egyáltalán nem fogtak ászkákat. A legtöbb ászkát az üde lápréten telepített csapdák gyüjtötték, melyek a csapdázás teljes anyagának $42 \%$-át fogták meg ( 80 példány). Innét mindössze két faj egyedei kerültek elő: A. zenckeri $(91 \%)$ és T. rathkii $(9 \%)$. A magassásos élöhelyen lerakott csapdák 35\%-kal (66 példány) a második helyen áll- 
2. táblázat: A gyüjtött fajok listája

\begin{tabular}{|l|c|c|}
\hline Fajnév (Species) & $\begin{array}{c}\text { Egyeló gyâjtés } \\
\text { (Hand sampling) }\end{array}$ & $\begin{array}{c}\text { Talajcsapdázás } \\
\text { (Pitfall traps) }\end{array}$ \\
\hline 1. Ligidium hypnorum Verhoeff,1901 & $\mathrm{x}$ & $\mathrm{x}$ \\
\hline 2. Haplophthalmus mengii Zaddach 1844 & $\mathrm{x}$ & - \\
\hline 3. Hyloniscus riparius Koch, 1838 & $\mathrm{x}$ & $\mathrm{x}$ \\
\hline 4. Trichoniscus pusillus Brandt, 1833 & $\mathrm{x}$ & - \\
\hline 5. Platyarthrus hoffmannseggii Brandt, 1833 & $\mathrm{x}$ & - \\
\hline 6. Trachelipus rathkii Brandt, 1833 & $\mathrm{x}$ & $\mathrm{x}$ \\
\hline 7. Porcellium collicola Verhoeff,1907 & $\mathrm{x}$ & $\mathrm{x}$ \\
\hline 8. Armadillidium vulgare Latreille, 1804 & $\mathrm{x}$ & $\mathrm{x}$ \\
\hline 9. Armadillidium zenckeri Brandt, 1833 & $\mathrm{x}$ & $\mathrm{x}$ \\
\hline
\end{tabular}

nak. Itt a gyüjtött ászkák többségét két faj adja: $A$. zenckeri $(62 \%)$ és $T$. rathkii $(30 \%)$. Néhány egyeddel az $A$. vulgare és a $H$. riparius egyedei is elökerültek. A Tetves-patak közeli keményfa liget fragmentumból 32 példány került elő $(17 \%)$. Az élöhely domináns faja $4 \cdot 1 \%-k a l$ itt a $L$. hypnorum, mely az előző élőhelyekről nem került elő. A legkevesebb egyedet a zsombékosban és az égererdőben lerakott csapdák gyüjtötték. Előbbiben a $H$. riparius 4 és a $T$. pusillus 5 példánya, utóbbiban a $T$. rathkii 2 és a $P$. collicola 1 példánya került elö.

Az avar rostálásával és a korhadt fák kérgének lehántásával több faj egyedeit találtuk meg, mint a talajcsapdák anyagában. Az egy élöhelyen, talajcsapdával gyüjtött legmagasabb fajszámnál (7) kettővel többet találtunk az akác-füz-éger ligetben, ahol az eddig felsorolt fajokon kívül itt előkerültek a $P$. hoffmannseggii, továbbá a $H$. mengii példányai is (3. táblázat).

Azz áprilisban végzett, majd augusztusban megismételt egyelő gyüjtések során sem találtunk ászkákat a homoki gyepekben és a fiatal tölgyesben.

3. táblázat: Az egyes élőhelyeken gyüjtött fajok egyedszámai. Az élőhelyek betü és szám kódjai megegyeznek az 1. táblázatban leírtakkal

\begin{tabular}{|l|c|c|c|c|c|c|c|c|c|c|}
\hline \multirow{2}{*}{ Fajok (Species) } & \multicolumn{6}{|c|}{ Góhelyek (S ampling sites) } \\
\cline { 2 - 12 } & $\mathbf{A}$ & $\mathbf{B}$ & $\mathbf{1}$ & $\mathbf{2}$ & $\mathbf{3}$ & $\mathbf{4}$ & $\mathbf{5}$ & $\mathbf{6}$ & $\mathbf{7}$ & $\mathbf{8}$ \\
\hline L. hypnorum & 3 & 1 & - & 13 & - & - & - & - & - & - \\
\hline Haplophthalmus sp. & - & 1 & - & - & - & - & - & - & - & - \\
\hline H. riparius & 3 & 12 & - & 2 & - & - & 1 & - & 4 & - \\
\hline Trichoniscus sp. & 6 & 5 & - & 4 & - & - & - & - & 5 & - \\
\hline P. hoffmannseggii & - & 20 & - & - & - & - & - & - & - & - \\
\hline T. rathkii & 2 & 1 & 2 & 6 & - & - & 20 & 7 & - & - \\
\hline P. collicola & 9 & 1 & 1 & 1 & - & - & - & - & - & - \\
\hline A. vulgare & 1 & 3 & - & 5 & - & - & 4 & - & - & - \\
\hline A. zenckeri & 3 & 1 & - & 1 & - & - & 41 & 73 & - & - \\
\hline
\end{tabular}




\section{Értékelés}

\section{Faunisztika}

A területről kimutatott fajok száma a hazai fauna $19 \%$-át, míg a Somogy megyei fauna 37\%-át teszi ki. Négy faj (a közép-európai elterjedésü $P$. collicola, és $H$. riparius, a kozmopolita, valamennyi földrészen megtalálható $A$. vulgare és az Európa-szerte elterjedt $T$. rathkii) mind országos, mind megyei viszonylatban a leggyakoribbak közé tartozik (FARKAS 1999). A szintén Európa-szerte megtalálható T. pusillus országos elterjedését tekintve mindössze négy publikált adattal rendelkezünk, melyek Kőszegről és az Északi középhegységből származnak (KESSELYÁK 1937, 1930, 1936, DuDICH 1942). Ennek ellenére valószínüsíthető, hogy gyakori, az egész országban elterjedt fajról van szó, melynek kicsiny mérete $(2,4-3,7 \mathrm{~mm})$ miatt meghatározása problematikus és a talajcsapdák anyagában többnyire alul reprezentált, vagy hiányzik, holott az adott élőhely talajának felső néhány $\mathrm{cm}$-ében magas denzitással van jelen. Nyirkos talajokban többnyire megtalálható. A Somogy megye egész területére kiterjesztett, szisztematikus faunisztikai kutatás során a több, mint száz megvizsgált élőhely 47\%-ában megtaláltuk (FARKAS nem publikált adatai). Az eddig felsorolt fajok tehát nem tekinthetők kifejezetten a látrányi terület élöhely-típusaira jellemzőknek, inkább országszerte gyakori, közönséges fajoknak, melyek elterjedése függetlennek látszik a tájegység és az élőhely típusától.

Ezzel szemben két további faj egyedeinek jelenléte szoros korrelációt mutat bizonyos élőhelyekkel. Az Észak-, Közép- és Dél-Európában élő L. hypnorum tavak, folyók, kisebb vízfolyások állandóan nedves szegélyén, gyakran a sáros talaj felszínén, korhadó növények alatt, továbbá az állandóan párás, hüvös szurdokvölgyek alján, az avarban él (GRUNER 1966). Érzékeny a levegő páratartalmára, száraz környezetben percek alatt elpusztul. Országos elterjedési adatai szintén nem tükrözik valós helyzetét: 1998-ig ismert volt Nyugat-Magyarországról (DUDICH 1942, KesSELYÁK 1937), ezen kívül a Dráva-ártér (FARKAS 1998a, 1998b) és a Bükk néhány helyén (ALLSPACH 1996) gyüjtötték. Somogyban viszont 2001-2002-ben a vizsgált élöhelyek 32 \%-ából kimutattuk, tehát ritka fajnak semmiképpen nem tekinthető. Az elöző fajhoz hasonlóan az Északkelet- és Közép-Európában élő $A$. zenckeri szintén az állandóan nedves, mocsaras élőhelyeket kedveli, de előnyben részesíti a nyílt vegetációjú területeket. Korábban mindössze Balatonberényről (SzLÁvECz 1992) és Ócsáról (SALlAI 1993) voltak adatai, ami alapján a ritka fajok közé sorolták, utóbb azonban a Hanságból, Baranya több pontjáról és Somogy megyében a vizsgált élőhelyek $24 \%$-ából is elökerült. Előfordulási helyein tömeges. Az Európában széles körben elterjedt $P$. hoffmannseggii myrmecophil faj, kizárólag hangyabolyokban él. Korábban ismert volt a Magyar Középhegységböl, Nyugat-Magyarországból és a Dráva-ártérröl (ForRó és FARKAS 1998). Az elmúlt évben Somogy több pontján is megtaláltuk. A $H$. mengii egyetlen példánya az akác-éger ligetböl került elö. A kis termetü (2-4 mm), rejtett életmódú faj korhadó fák kérge alatt él. Egész Európában elterjedt (GRUNER 1966), de hazánkban csak Észak- és Nyugat-Magyarországról (Dudich 1928, 1942, Ilosvay 1985, Kesselyák 1936, 1937, Strouhal 1965) valamint a Dráva-síkról (FARKAS 1998b) voltak ismert adatai. Eddig Somogy megye 5 UTM négyzetéből került elö.

\section{Ökológia}

$\mathrm{Az}$ öt élőhely ászkaközösségeit a Rényi-féle diverzitási függvényekkel hasonlítottuk össze (1. ábra). A terület keleti határán húzódó efemer vízfolyás menti keményfa liget fragmentum Rényi-diverzitása bizonyult a legmagasabbnak. A fajszám itt volt a legnagyobb és az egyedek megoszlása a legegyenletesebb. Két, talajcsapdával általában nem gyüjthetö faj (H. mengii, $P$. hoffmannseggii) kivételével minden fajt megtaláltunk a csapdák anyagában. Az egyelő gyưjtések során a rejtett életmódú fajok is előkerültek. A Drá- 


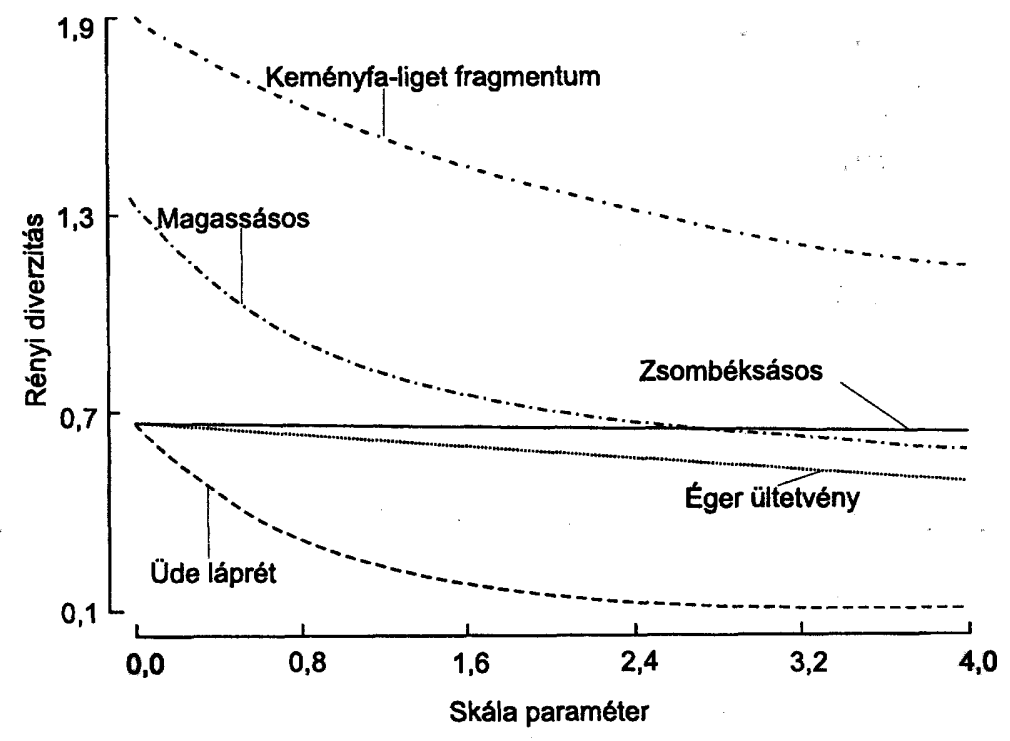

\section{1. ábra: A különböző élőhelyek ászka fajok alapján számított Rényi-féle diverzitási profiljai}

va mentén, több, mint 70 élőhelyen végzett mintavételek eredményei alapján, egy élőhelyen átlagosan 4-5 ászkafaj él (FARKAS 1999). Így magasnak tekinthető az a fajszám (9), melyeket ezen élöhely egy 8-10 $\mathrm{m}^{2}$-es foltjában tapasztaltunk. Az állandóan nedves, laza talaj egyrészt magas, $85 \%$ feletti páratartalmat biztosít, másrészt az állatok könnyen elbújhatnak a morzsalékos talaj darabkák és a korhadó ágak között. A fák árnyékoló hatása miatt a hőmérséklet emelkedését az ászkák még tolerálják, továbbá lehullott lombjuk és a számos kétszikü, lágyszárú növény maradványai jó minőségü táplálékot biztosítanak (RUSHTON és HASSALl 1983). Az itt élö ászkaközösség domináns faja a $L$. hypnorum (41\%). Mellette megtalálható az országosan és megyei viszonylatban egyaránt leggyakoribb 5 faj (H. riparius, $T$. pusillus, T. rathkii, $P$. collicola és $A$. vulgare), együttesen 56\%-os arányban. A kis számban elöforduló $A$. zenckeri egyedei a szomszédos láprétröl származnak.

$\mathrm{Az}$ égerligetek és a homokdombok közötti, mélyebben fekvő területeken magassásosok és üde láprétek Isopoda együttesei markánsan különböznek az elöző élőhelytől. Az itt élő ászka együttes kevesebb (4) fajból áll, viszont az egyedszámok hasonló arányban oszlanak meg, amit a két élöhely diverzitási profilja is tükröz: a magassásos görbéje a keményfa liget alatt húzódik, azzal közel párhuzamosan. A növényzet magassága a magassásosokban az $1 \mathrm{~m}$-t is meghaladja, borítása $100 \%$, emiatt a nedves talaj feletti pára megreked és folyamatosan $90 \%$ felett marad, ami az ászkarákok számára kedvező. A nedvesség állandó jelenlétét jelzi egyes Amphipoda fajok jelenléte is. A fák árnyékolásának hiánya miatt azonban a hőmérséklet kedvezőtlenül magas értékeket érhet el, amit a kisebb termetü, vagy gyengén kitinizált fajok kevésbé tolerálnak. A zömmel egysziküekből álló növényzet nyújtotta táplálékkínálat sem kedvezö. A legnagyobb arányban $(62 \%)$ a mocsárrétek ökológiai viszonyaira specializálódott $A$. zenkeri volt jelen. Mellette $30 \%$-os részesedéssel az elsösorban ártéri erdökben tömeges $T$. rathkii-t találtuk (3. ábra).

Az üde láprét diverzitási profilja a legalacsonyabb értékről indul ( 2 fajból áll az együttes) és a legalacsonyabban húzódik. A növényzet magassága csak 20-30 cm, ezért itt a közvetlen napsugárzás és annak melegítő hatása jóval eröteljesebb, emellett a páratarta- 


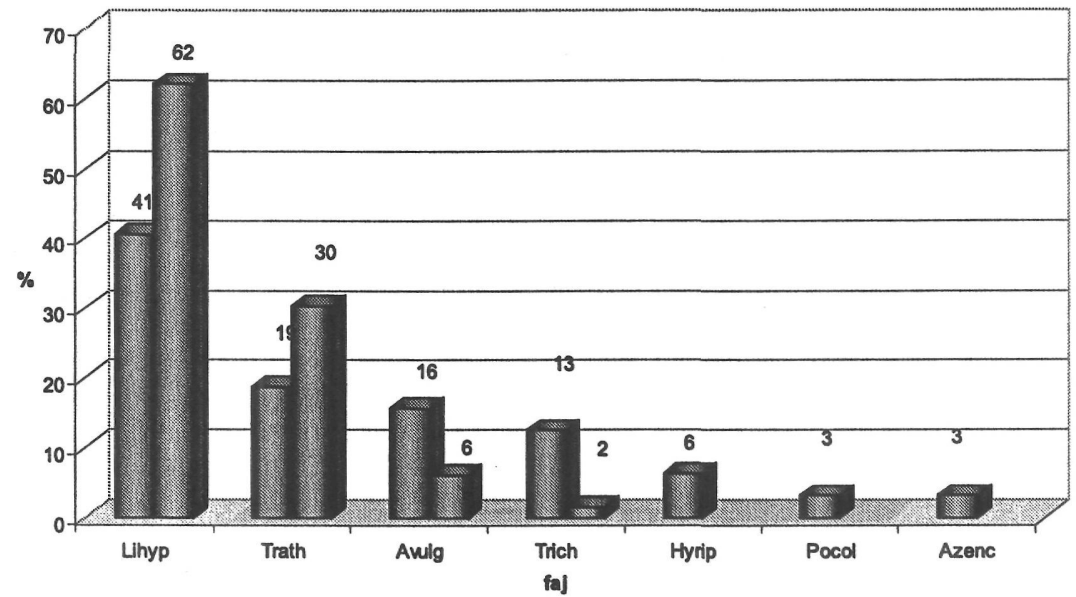

2. ábra: Az ászka fajok egyedeinek százalékos megoszlása a keményfa-liget fragmentumban

lom is alacsonyabb. Ezeket a körülményeket az itt élö fajok közül csak az A. zenckeri képes tolerálni. E faj számára ez az élőhely a legmegfelelőbb, amit egyrészt az is jelez, hogy a legtöbb példányt az itt lerakott csapdák gyüjtötték, másrészt, hogy az itt gyüjtött anyag $91 \%$-át e faj alkotta. Mellette még a $T$. rathkii néhány példánya került elő.

Az évszázadok óta érintetlen homoki gyepek ökológiai viszonyai kedvezőtlenek az ászkák számára. HoRNUNG $(1984,1993)$ kiskunsági homokbuckákon végzett vizsgálatai során csak a buckaközökben kialakult gyepfoltokból került elő két faj ( $A$. vulgare és $T$. nodulosus) viszonylag alacsony egyedszámban. A látrányi terület homokdombjai között nem alakultak ki a kiskunságihoz hasonló növénytársulások. A dombokon a felszín hőmérséklete nyáron elérheti az $50^{\circ} \mathrm{C}$-ot, ugyanakkor vizet nem tartalmaz. A kedvezőtlen hömérsékleti és vízviszonyok mellett a táplálékkínálat is szegényes, föként egyszikủekből áll. Mindezen hatások miatt erröl az élőhelyről hiányoztak az ászkák.

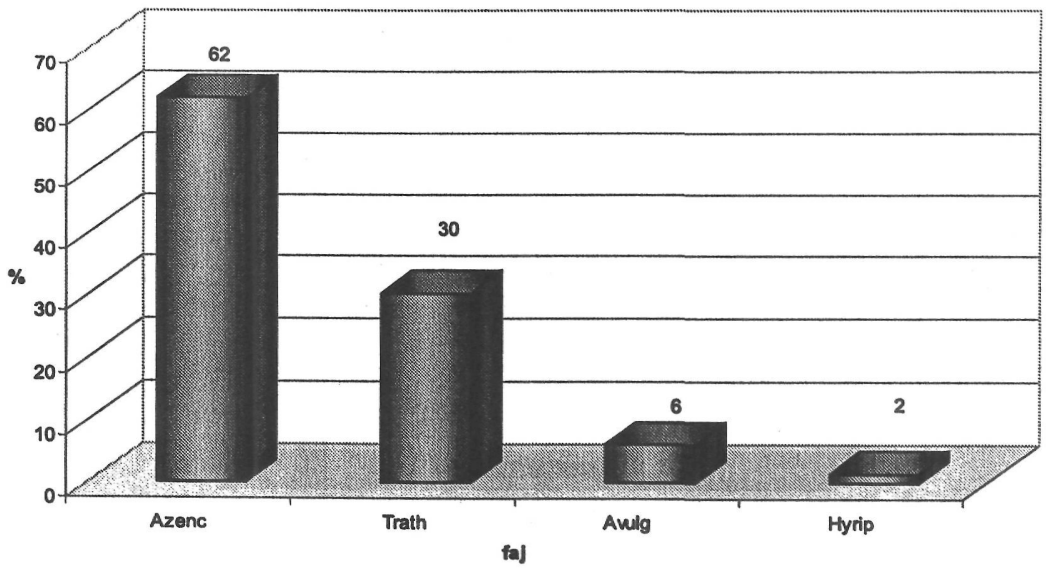

3. ábra: Az ászka fajok egyedeinek százalékos megoszlása a magassásosban 
A 67-es föút és az andocsi út közötti területeken a haszonfa ültetvények (éger, tölgy) helyén korábban homoki gyepek lehettek, melyekben ászkák ugyanúgy nem éltek, mint a jelenlegi gyepekben. Mindössze az égeresböl került elö a $P$. collicola és a $T$. rathkii egy ill. két példánya. Ebben a homoktalaj rossz vízmegtartó képessége játszik szerepet, valamint a mintavételi helyek tengerszint feletti magassága (tölgyes: $130 \mathrm{~m}$; égeres: $131 \mathrm{~m}$ ) együttesen magyarázza, hogy bár a táplálékkínálat és a hőmérséklet kedvezőbb, mégsem alakulhattak ki ászkaközösségek ezen élöhelyeken. A tengerszint feletti magasság adatokat összehasonlítva a többi vizsgált élöhellyel kitünik, hogy a fajgazdagabb élőhelyek mindig több méterrel alacsonyabban fekszenek (1. táblázat). A tölgyesben elhelyezett csapdák egyetlen példányt sem gyüjtöttek. A megismételt mintavételt egy több hetes, csapadékos, hüvös periódust követően végeztük, ami fokozza nyáron az ászkák aktivitását, de ennek ellenére sem jártunk eredménnyel. Feltünő volt az avarfauna szegényessége: az ászkák mellett a további, avarlakó csoportok (Arachnoidea, Diplopoda, Coleoptera, stb.) képviselői is hiányoztak, vagy csak néhány példányukat találtuk. Hasonló jelenséget tapasztaltunk Somogy megye több homoki erdejében is (Kaszó, Szenta, Bolhás, Balatonszentgyörgy). A május-júniusban elkezdődő meleg, száraz időszakban az erdei homoktalajok felső rétege $30-40 \mathrm{~cm}$ mélyen is teljesen kiszárad. A gyors, nyári záporok, de még a több napos, kiadós esőzések is csak az avart, esetleg a talaj 1-2 cmes rétegét nedvesítik át. Ezek körülmények nem teszik lehetővé ászkapopulációk tartós megtelepedését.

A kutatást az MTA Bolyai János Kutatói Ösztöndíja támogatta (BO/00304/01).

\section{Irodalom}

AlLPASCH A. 1996: The Terrestrial Isopods of the Bükk National Park (Crustacea; Isopoda; Oniscidea). - in: Mahunka, S. (ed.): The Fauna of the Bükk National Park, II. - Hungarian Natural Hystory Museum, Budapest. 71-74.

DuDICH E. 1928: Faunisztikai jegyzetek III. - Állatt. Közl. 24: 38-45.

DuDICH E. 1942: Nachträge und Berichtigungen zum Crustaceen -Teil des ungarischen Faunenkataloges II. Frag. Faun. Hung. 5: 1-13.

FARKAS S. 1998a: The Isopoda fauna of the Rinya-region I. Bakháza (Hungary). -Somogyi Múzeumok Közleményei 13: 257-262.

FARKAS S. 1998b. The faunistic results of the study of woodlice (Crustacea: Isopoda) along the river Drava (South Hungary). - Studia Pannonica 9: 123-130.

FARKAS S. 1999: Isopodák szünbiológiai vizsgálata a Dráva-ártéren. - PhD értekezés. JATE, Szeged.

FORRó L., FARKAS S. 1998: Checklist, preliminary distribution maps, and bibliography of woodlice in Hungary (Isopoda: Oniscidea). - Misc. Zool. Hung. 12: 21-44.

GRUNER H.-E. 1966: Krebstiere oder Crustacea V. Isopoda 2. - in: Die Tierwelt Deutschlands und der angrenzenden Meeresteile. Ved Gustav Fischer Verlag, Jena.

HoRNUNG E. 1984: Characteristics of the population of an Isopoda species (Trachelipus nodulosus C.L. Koch) at sandy soil grassland. - Acta. Biol. Szeged. 30: 153-158.

HORNUNG E. 1993: Szárazföldi Isopoda populációk reproduktiv stratégiái és tér-idő mintázata. - Kandidátusi ćrtckezés. JATE, Szeged.

KESSELYÁK A. 1930: Faunistisches über Isopoden. - Zoolog. Jahrbücher Abt. Syst. 60: 239-256.

KESSELYÁK A. 1936: Bars vármegye szárazföldi ászkarákjai. - Állatt. Közl. 33:142-148.

KESSELYÁK A. 1937: A kőszegi hegység szárazföldi ászkarákfaunája. - Vasi Szemle 4: 89-96.

RuSHTON S.P., HASSALL M. 1983: The effects of food quality on the life history parameters of the terrestrial isopod (Armadillidium vulgare (Latreille)). Oecologia (Berlin) 57: 257-261.

SAlla Á. 1993: Ecofaunistical investigations in a boggy forest in the Protected Landscape Area at Ócsa (Kiskunság National Park, Hungary). - Opusc. Zool. Budapest 26: 85-94.

SCHMÖLZER K. 1965: Ordnung Isopoda. Akademic Verlag, Berlin. 
Strouhal H. 1965: Dic Haplophthalmus-Arten Ungarns (Isopoda terrestria). - Acta. Zool. Hung. 11: 465-473.

SzLÁVECZ K. 1992: The role of terrestrial isopods (Isopoda: Oniscidea) in the decomposition of aquatic macrophite detritus of lake Balaton, Hungary. - Opusc. Zool. 25: 103-112.

TóTHMÉRÉsz, B. 1996: NuCoSA 1.05. Programcsomag botanikai, zoológiai és ökológiai vizsgálatokhoz Scientia Publishing, Budapest.

\section{The terrestrial isopod (Isopoda: Oniscidea) fauna of the Látrányi Puszta Nature Conservation Area}

\section{SÁNDOR FARKAS AND EDIT VADKERTI}

The Isopod fauna of Látrányi Puszta Nature Conservation Area was uncovered. A faunistical and ecological research was started in 2002 to discover the woodlice species living there and to study the community structure and habitat preference of the Isopod assemblages. Pitfall traps and hand collecting were used as sampling methods. All the habitats were sampled that are characteristic in the Area: sandy grassland, fragment of wetland forest, marsh, alder and oak woods. A total of 262 isopod specimen were captured which belonged to 9 species: Ligidium hypnorum, Haplophthalmus mengii, Hyloniscus riparius, Trichoniscus pusillus, Platyarthrus hoffmannseggii, Trachelipus rathkii, Porcellium collicola, Armadillidium vulgare, Armadillidium zenckeri. These species were uncharacteristic in the examined habitats except of Ligidium hypnorum and A. zenckeri that live mainly in wet, humid places. All the other species are common and widely distributed in Hungary. The Isopod assemblage of the wetland forest had the highest Rényi-diversity value. 